\title{
Real and Semi-Real - an Architectural Backstory for Flusser's Dual Scientific Fictions
}

\section{Real e semirreal - um fundo arquitetônico para as ficções científicas duais de Flusser}

\section{William Hanff ${ }^{1}$}

DOI: $10.19177 /$ memorare.v8e1202181-92

\begin{abstract}
Vilém Flusser's approaches to epistemology and science fiction are explored in connection with the fictionalism of Hans Vaihinger and other late $19^{\text {th }}$ and early $20^{\text {th }}$ century philosophies, as well as using an architectural metaphor of scaffolding and blueprints. From his 1980 essay "Science Fiction" Flusser's two approaches to science fictions are labeled as 1) a 'falsification strategy' and 2) an 'epistemology of improbability.' These are further explored as metaphors for architecture and building based on ideas from his "Wittgenstein's Architecture" in The Shape of Things: a Philosophy of Design and compared and contrasted with visual metaphors of the fantastic in the paper architecture called The Obscure Cities series by François Schuiten and Benoît Peeters. Further reinforcing the connection between Flusser's and Vaihinger's philosophies, semi-fictions and real fictions are envisioned as a type of new media architecture.
\end{abstract}

Keywords: Fictionalism. Vilém Flusser. Science Fiction.

Resumo: As abordagens de Vilém Flusser à epistemologia e à ficção científica são exploradas em conexão com o ficcionalismo de Hans Vaihinger e outras filosofias do fim do século 19 e início do século 20 e com uma metáfora arquitetônica de andaimes e desenhos técnicos. As duas abordagens de Flusser às ficções científicas, de seu ensaio de 1980 "Science Fiction", são rotuladas como 1) uma 'estratégia de falsificação' e 2) uma 'epistemologia da improbabilidade'. Ambas são exploradas como metáforas para arquitetura e construção com base nas ideias de seu ensaio "Wittgenstein's Architecture" (em The Shape of Things), e comparadas e contrastadas com metáforas visuais do fantástico na arquitetura de papel da série As cidades obscuras, de François Schuiten e Benoît Peeters. Para reforçar ainda mais a conexão entre as filosofias de Flusser e Vaihinger, as semificções e as ficções reais são vistas como um tipo de arquitetura de novas mídias.

Palavras-chave: Ficcionalismo. Vilém Flusser. Ficção científica.

\footnotetext{
1 William A. Hanff Jr. is an Assistant Professor of Digital Media at the University of the District of Columbia teaching communications theory, cinema history and digital production. He received his Ph.D. in Media Philosophy from the European Graduate School (EGS) in 2006 with the dissertation "Documentary Simulations: An Epistemology of Hoax \& Paradox"; and a Master of Science (M.S.) from Boston University in 1996 in Broadcasting. William researches in areas of suspension-ofdisbelief/dissimulation, archetypes, the history of science, documentary film as well as pedagogy of digital media. William is a DC native and filmmaker specializing cult cinema and politics.
} 
Among the most compelling aspects of Vilém Flusser's philosophy is his conceptualization of fictions within science as a means of uncovering truth. From his ideas of apparatus theory, to the differences between humans and vampyroteuthis, to his thoughts on design and architecture, Flusser remained open to conceiving of a systematic search for a potentially ontological 'truth', while allowing for various fictions to interplay with verifiable facts as part of a system of uncovering. This reaches a highpoint in his later career in his two works Da dúvida (1966) translated as On Doubt (2014) and "Science Fiction" (1988) translated (2015). In his introduction to On Doubt Flusser states "Doubt, allied to curiosity is the cradle of research, therefore of all systematic knowledge" but then he immediately warns of the intellectualization or concentration of doubt that, "In a distilled state doubt kills curiosity and is the end of all knowledge." (p. 3) This paradoxical 'doubt of doubt' undoes most of the search for both truth and useful technology brought about by a scientific epistemology. However, Flusser provides a potential backstop against this by embracing and expounding a dual approach to gaining truth through scientific fictions in balance with unknowns and epistemic doubt:

In one such epistemology, nothing can go about arriving at truth, but instead approach truth more and more, by applying two complementary strategies. One is that all probable, ([but still] fictional) ostensible statements made appear progressively, so that they are always more and more probably and less and less improbable. This can be called the strategy of 'falsification.' The other strategy is to be able to accurately measure possible degree of improbability of any statement (their 'margin of error'), ...in order to be able to work with the imprecision ("fuzziness") as precise as possible. $(2015$, p. 2$)$

This system is the architectural equivalent of building a scaffolding around the truth in order to build up toward truth by uncovering more and more probabilities to the structure that is emerging. These conscious improbabilities, these science fictions, will eventually be discarded. Practioners of this form of scientific discovery through 'falsification' use doubt as a figurative construction tool for carving out or building up verifiable probabilities into a coherent and useful structure and then later removing the mental scaffolding of improbabilities and discarded hypotheses. There is a paradox at the heart of this method. Again, in his introduction to 'On Doubt' Flusser accedes to the problem, "Doubt may be, therefore conceived as a search for certainty that starts by destroying authentic certainty in order to produce inauthentic certainty. Doubt is absurd." (p. 2) This is overcome by the fact that doubt is used only temporarily in the process of falsification, in the same manner that a mental scaffolding of science fictions, or hypotheses are only temporary. "Doubt of doubt is a fleeting state of mind. Although it can be experienced, it cannot be sustained. It is its own negation." (p. 4)

Flusser contrasts this 'strategy of falsification' with a second approach of making statements that are wildly improbable, but then allowing for the reduction to the absurd to approach the truth from the side of nearly pure fiction or almost fantastic fabulation. From his 
lecture "Science Fiction" he gives some examples of precedents to this 'epistemology of improbability'.

With some imagination, we can now think of an epistemology that goes the opposite way. Such an epistemology would be about making statements that are more and more improbable, in order to, so to say, approach the truth from the opposite side. This type of strategy has always existed, for example among the traditions of the [Gnostic] Scholastics and in the [esoteric study of] the Talmud. Both are attempts to reach enlightenment by reduction to the absurd [reductio ad absurdum], to somehow find the truth. (2015, p. 2)

The type of truth that Flusser is postulating here is not the same as the semi-practical 'strategy of falsification' of using doubt to measure or carve away 'fuzziness', but a more metaphysical truth that can establish a network or chain of creativity and avoid the pitfall of the absurdity of doubt of doubt. Flusser works to overcome this paradox with an essential Ungenauigheit, an inexactitude in both fictions and in the study of science. This inexactitude is the space for serendipitous discovery and rediscovery in the technical progress in scientific epistemology. At the same time, Flusser advocates for the fantasia essata, an exactitude in imagined fantasy. This is both practical, in the realm of scientific discovery and design, and theoretical, in the realm of literary theory and narratology.

\section{Potential Backstories}

Where does Flusser look to find examples for this Ungenauigheit and fantasia essata? What is the philosophical backstory of leaving inexactitude in scientific fictions, but requiring exactitude in fantastical science fiction? Flusser gives the immediate examples of medieval gnostic scholars and esoteric talmudists, but there are other intermediate influences that pointed toward his 'epistemology of improbability' through reductio ad absurdum. While Flusser was largely an autodidact, and belonged to no particular school or theory of $20^{\text {th }}$ century philosophers, his dual approaches to seeking truth, of fictions within science, can be traced to several sources that would have exerted a cultural or philosophical influence on the overall culture of Europe during Flusser's formative years. For example, Wilhelm Windelband's differentiation between the nomothetic approach of natural sciences and the idiographic approach of social sciences is an example of a connection to Neo-Kantian ideas that runs parallel to Vilém Flusser's ideas of the dual approaches of reaching truth. In this Neo-Kantian sense, Flusser's falsification is mostly a tactical strategy while his improbability is mostly an ontological epistemology.

Most of the scholars of Flusser's work acknowledge the influence of Nietzsche in general and "On Truth and Lies in a Non-Moral Sense" in particular. Anke Finger reinforces Flusser's connection to Hans Vaihinger in the chapter "Science as Fiction, Fiction as Science" in Vilém Flusser an Introduction. He also mentions the fiction of Karel Capek and the rabbinic exegetical game of 'pilpul'. Indeed, Vaihinger's doctoral dissertation from 1877, which he re-worked across several decades into Die Philosophie des 'Als-Ob' and published in 1911, established itself as one of the most important works in approach now called fictionalism. 
While there are some roots of fictionalism in $18^{\text {th }}$ century British writers such as Berkeley and Hume, much of the backstory to fictionalism appears in late $19^{\text {th }}$ century German empiricism and phenomenology. Vaihinger condensed much of this thinking into his work. Translated into English in 1924, The Philosophy of As-If almost certainly holds an important position in Flusser's two approaches to seeking truth through fictions within science. It would have been read in Vienna, Prague, and London at the time Flusser was matriculating. Vaihinger establishes fictionalism within the realm of continental phenomenology. For example, Vaihinger suggests a source for these approaches to fictions and science in the structure of thought itself.

"If thought is regarded as a biological function, it is obvious that these are impossible problems for thought to solve, and quite beyond the natural boundaries which limit thought as such. From this point of view, we have no inclination to fall back on the favourite old grievance about the limitations of human knowledge."

"A moment of reflection will show that all knowledge is a reduction of the unknown to the known, that is to say a comparison. This proves therefore that this comparison or reduction will somewhere stop automatically." (2009, p. xliii)

This reduction of the unknown to the known is similar to Flusser's 'falsification strategy' and that there are natural boundaries to thought itself that work to limit the paradoxical effects of the 'doubt of doubt'. Like Wittgenstein, Vaihinger believes that the structures of thought in general and in language in particular can easily lose connection to the biological problem they evolved to solve, and lead to paradoxes.

For thought originally only serves the Will to Life as a means to an end, and in the direction also it fulfills its function. But when thought has broken loose from its original aim, according to the Law of the Preponderance of the Means over the End, and has become an end in itself, it sets itself problems to which it is not equal because it has not developed for this purpose. (2009, p. xliii)

This preponderance of the means over the ends became a key point in Vaihinger's overall study of fictionalism and his philosophy of 'As-If'. It is likely that this axiom is at the root of Flusser's thinking on science fictions as well. For Vaihinger fictions are more epistemologically complex, and they are both the process and the production of their creative activity. They are always already a means.

Fictio means, in the first place, an activity of fingere, that is to say, of constructing, forming, giving shape, elaborating, presenting, artistically fashioning: conceiving, thinking, imagining, assuming, planning, devising, inventing. Secondly, it refers to the product of these activities, the fictional assumption, fabrication, creation, the imagined case. (2009, p. 81)

\section{Semi-Fictions and Real Fictions}

However, the best connection between the Flusser and Vaihinger comes from their exceedingly similar categorization of fictions. After separating out fantasy/figments and aesthetic fictions, Vaihinger works to differentiate categories in practical fictions used both philosophically and scientifically into 'semi-fictions' and real fictions. He reinforces the idea: 
“...they must be kept rigidly distinct. The semi-fiction first encountered was that of artificial classification and the method of abstraction and we then concluded with a discussion of real fictions - the Atom, the Infinite, and the Thing-in-itself. The transition between is represented by the practical fictions (IX), and it is at this point the pure fictions begin." (2009, p. 78)

These fictions may still have an aesthetic component (in fact, many do) but they function, for Vaihinger, like an extension of logical questioning "...taking fiction in its broadest sense of fictive activity, we place it on equal footing with deduction and induction as a third member in the system of logical science." (p. 79) In this system, the semi-fictions are temporary intentional deviations from reality created with a specific utility in mind-Vaihinger's semi-fictions align with Flusser's 'falsification strategy' - they are the equivalent of scaffolding, a caisson, or a mold for the creation of a building, bridge, or concrete wall. These architectonic metaphors are drawn in the tradition of early century theories of phenomenology of architecture from the writings of Gaston Bachelard and Ernesto Rogers specifically, and Martin Heidegger and Edmund Husserl more broadly.

In this same system a true fiction is always a contrivance for the purpose of communication or explication. It serves as a mental (and sometimes literal) model to stimulate thought. In fact, the word "real" in real fictions could have self-conscious quotations marks around it, because the more 'real' it is, the more it is a fiction, closer to a form of art, and further from the actual state of things. Vaihinger explains, "...that the true fiction, formulated in a strictly scientific manner, is always accompanied by the consciousness that the fictional idea, the fictional assumption has no real validity." Vaihinger's real fictions behave the same way that Flusser's 'epistemology of improbability' does-they are the equivalent of blueprints, architectural renderings, or miniature models for the design of a building, bridge, or wall.

In fact, Chapter Nineteen of The Philosophy of As-If entitled "Introductory Remarks on the Position of Fictions and Semi-fictions in the Logical System as a Whole" Vaihinger gives a detailed differentiation between semi-fictions and real fictions. It is uncanny how closely this matches Flusser's differentiation between 'falsification strategy' and 'epistemology of improbability'. For the purposes of quotation, the text can be formatted into a table (next page) for comparison and contrast along with Flusser's two approaches and the architectonic metaphor for a visualization of the differentiations. 


\begin{tabular}{|c|c|}
\hline $\begin{array}{l}\text { Vaihinger's Semi-Fictions } \\
\text { Flusser's 'falsification strategy' } \\
\text { (Metaphor: Scaffolding/Mold) }\end{array}$ & $\begin{array}{l}\text { Vaihinger's Real Fictions } \\
\text { Flusser's 'epistemology of improbability' } \\
\text { (Metaphor: Blueprint/Model) }\end{array}$ \\
\hline $\begin{array}{l}\text { Provisional concepts destined to be replaced later or } \\
\text { corrected }\end{array}$ & Are simply there to facilitate logical communication \\
\hline Historically provisional fictions & Logically provisional fictions \\
\hline Disappear in the course of time & Are omitted in the course of the operation \\
\hline “Conscious mistakes" & "Conscious contradictions" \\
\hline Tend to serve purely practical purposes & Tend to serve theoretical purposes \\
\hline Used for logical "operations" & Used for "understanding" \\
\hline Lead us back to methodological motives & $\begin{array}{l}\text { Leads to those [motives] connected with the theory of } \\
\text { knowledge }\end{array}$ \\
\hline More in the nature of an indirect method & More in the nature of an incorrect concept \\
\hline $\begin{array}{l}\text { Essentially ingenious, and substitutes something conceived } \\
\text { for something what is actually given }\end{array}$ & $\begin{array}{l}\text { Essentially artificial and blends the given with the } \\
\text { unthinkable }\end{array}$ \\
\hline $\begin{array}{l}\text { Assume the unreal-avoid difficulties by deviating from } \\
\text { reality }\end{array}$ & $\begin{array}{l}\text { Assume the impossible-create new difficulties and are } \\
\text { much more free with the given }\end{array}$ \\
\hline $\begin{array}{l}\text { Only falsifies reality with the object of discovering the } \\
\text { truth }\end{array}$ & $\begin{array}{l}\text { Makes reality incomprehensible-in order that it may } \\
\text { be comprehended }\end{array}$ \\
\hline Are only by-ways and cover the same ground & $\begin{array}{l}\text { Leave the earth and reality altogether and move about the } \\
\text { air }\end{array}$ \\
\hline Behave contrary to the facts & Behave in contradiction with the facts \\
\hline Substitute something different for reality & Interpolate impossible elements \\
\hline Are generally simpler than reality appears to be & Are more complicated [than reality appears to be] \\
\hline $\begin{array}{l}\text { Mistakes due to the former must be corrected if there is to } \\
\text { be a real advance. }\end{array}$ & $\begin{array}{l}\text { In the other case, errors can only be avoided if the concepts } \\
\text { are afterwards dropped }\end{array}$ \\
\hline $\begin{array}{l}\text { Mistakes due to semi-fictions are in conflict with the } \\
\text { objective state of affairs }\end{array}$ & $\begin{array}{l}\text { Real fictions are essentially formal mistakes in thought, } \\
\text { logical mistakes }\end{array}$ \\
\hline Proceed along by-ways and short-cuts & Proceed along forbidden paths \\
\hline Semi-fictions modify what is given & $\begin{array}{l}\text { Real fictions infect [what is given] with elements which } \\
\text { do not belong to it, but yet serve to render it } \\
\text { comprehensible }\end{array}$ \\
\hline
\end{tabular}

(2009, pp. 80-81)

And while each of these statements appear to work as well for Flusser's two approaches as for Vaihinger's two types of fiction, two stand out in particular, and are worth fully quoting and exploring: "for while the semi-fiction only falsifies reality with the object of discovering truth. the fiction proper makes reality incomprehensible-in order that it may be comprehended." (p. 80) Flusser's 'epistemology of the improbability' also describes this paradoxical practice that is a form of art, making comprehension by bending reality in a specifically artful way. Similar to this Vaihinger's idea that “whereas semi-fictions modify what is given, real fictions infect it, to a certain extent, with elements which do not belong to it but yet serve to render it comprehensible." ( $p$. 81) Like the playful linguistic games can 'infect' proper grammar while making a language more facile, the gnostic mixture of fantastical folk science in alchemy or artfully drawn paper architecture that could be part of Flusser's 'epistemology of the improbability', this aspect of Vaihinger's real fiction allows elements that would be fantastical, or in 
his terms 'figments' to mutually coexist with practical fictions in the service of creating designs for technical applications.

In his work "A New Imagination" in Writings, Flusser expands on his dual approaches to fictions in science, explains how they can be used in tandem with each other.

"In this attempt to differentiate the two types of imagination from each other, a series of gestures has been mentioned. When they are taken in their totality, they offer a complete picture of human development. In this way: First, man took a step back from his life-world, to imagine it. Then, man stepped back from the imagination, to describe it. Then, man took a step back from the linear, written critique, to analyze it. And finally, owing to a new imagination, man projected synthetic images out of analysis."

(2008, p. 116)

This helps explain why the first approach acts as a strategy, as a 'falsification strategy', and the second approach is a broader, more creative epistemology, as an 'epistemology of improbability.' The synthetic images remain an important part of Flusser's work in apparatus theory. This new imagination works as a real fiction, as described by Vaihinger, and can create these new epistemologies of improbability. While the gesture of stepping back from the life-world to imagine it would almost by necessity create what Vaihinger calls semifictions that are part of the measuring the fuzziness, or 'falsification strategy' used to approach truth through fictions. Flusser believes that good art and sound scientific texts mesh these two approaches together. Again, in "Science Fiction" he states:

If we imagine such a 'science fiction', as a text whose statements become more and more improbable without ever completely losing sight of the truth, then we see beauty in the genuine sense of the term. Because apparition and beauty (deceit and art) are the two sides of the same coin. The decisive factor here is that such a "science fiction" as a counterscience would need to obey the same exact discipline as those of the scientific texts. $(2015$, p. 2$)$

And this has a direct connection with Vaihinger's ideas of creativity within the mind as it seeks to answer questions through fictions and testing.

"The fictive activity of the mind is an expression of the fundamental psychical forces; fictions are mental structures. The psyche weaves this aid to thought out of itself; for the mind is inventive; under the compulsion of necessity, stimulated by the outer world, it discovers the store of contrivances that lie hidden within itself. (2009, p. 12)

\section{Additional Contexts \& Architectonic Metaphors}

Further probing the backstory and influences on Vaihinger we find the expected influence of the Neo-Kantians and Kant himself. In fact, in his general introduction to The Philosophy of As-If, Vaihinger vehemently disagrees with the Hegelian dialectic, and considers it a type of falling into the trap of putting means over ends. Vaihinger states, "Actually the greatest and most important human errors originate through thoughtprocesses being taken for copies of reality itself;" (p. 8) in the footnote to this idea Vaihinger quotes directly from Kant's Prolegomena §40: "All illusion consists in holding the subjective ground of judgement to be 
objective." Reason falls into error "when it mistakes its destination, and refers transcendentally to the object what only concerns its own subject and its guidance in all immanent use." (p. 8) Vaihinger also grapples with F.A. Lange's 'standpoint of the ideal' and Nietzsche's theory of fictions. Lastly, and unexpectedly, Vaihinger explored Lazarus and Steinthal's proto-anthropology (Völkerpsychologie) which itself was rooted in the proto-psychology of Johann Herbart. And all of these philosophies would have been at least acknowledged in the early education of Vilém Flusser received in Prague.

And while it is impossible to draw an absolute direct connection between Vaihinger's ideas and Flusser's dual approaches, they nonetheless share a focus on the overlap between practical fictions and improbability. In fact, Flusser holds an interesting place in the study of theories of science and rational doubt. His formative years in Europe, his several decades in Brazil and a return to Europe later in his career allowed him to absorb and refine many disparate ideas about phenomenology and media. Flusser conceptualized much of his thinking on media theory in general while in Brazil, folding together NeoKantianism, Vaihinger's fictionalism, and a European-style anthropology that approached electronic media as though the media themselves were a place someone could migrate to despite their growing ubiquity, and learn new epistemologies. These ideas influenced his lectures and curriculum design for the Faculdade de Comunicação e Humanidades da Fundação Armando Alvares Penteado (FAAP) in the 1960s and his work on linguistics Língua e realidade, originally in Portuguese in 1963 and only translated later into Czech in 2005.

Despite the fact that the germ of Flusser's second stage of production, between 1973 and 1991, was already in the works of his Brazilian first phase, in which he "forged most of his theories" (Machado 2002: 27), the change of countries reflected in a change of content and orientation in his works. In his European works of the 80's there is an emphasis on media and communication theories and, the respective ideas, formerly developed in Brazil, only in this European phase would take the shape of a publication of important books. (Hanke, p. 3)

In some ways, Flusser's influence is only now being felt. His ideas from On Photography in particular, and on apparatus theory in general, have influenced not only academic writers, but designers and filmmakers. His influence by and on designers, comics/bande dessinée, and paper architecture is apparent from his short allegorical essay 'Wittgenstein's Architecture' in The shape of things: a philosophy of design. Here, the architectonic metaphor of scaffolding and building with cubes returns as a way to visualize the practical semi-fictions in linguistics and literary theory.

...somewhat apart from all these stands a small, apparently insignificant house resembling scaffolding more than a finished building: Wittgenstein's building. This little house is called the Tractatus. This name isn't the product of a one-track mind. For when one enters the house, one notices immediately that this is not a place that has lost track of things. Quite the opposite: It is a place of mirror-images. The house stands on six foundation pillars which support one another by means of cross-beams organized in a hierarchy. (2017, p. 76) 
Describing the history and tradition of Western literary thought as a jumble of disparate yet logically-consistent architectural forms, whether intentional or not, is a clear aesthetic and thematic connection to the Franco-Belgian work of paper architecture called The Obscure Cities series by François Schuiten and Benoît Peeters. Published between 1983 and 2005, Les Cités obscures, sometimes translated as Cities of the Fantastic in English, foregrounded the phenomenology of architecture in large-format folio-sized graphic novel format, and continued the intellectual tradition of exploring various social ideas and epistemologies through fantasy and retro sci-fi. The medium of comics/bande dessinée/manga has several advantages over architecture and cinema for exploring the fictionalism that is implicit in Flusser and Vaihinger. Schuiten and Peeters began their careers in this medium in the mid 1980s, near the time of Flusser's publication of On Photography. Many of Flusser's ideas of media theory are put into practical application by the artistic works of Schuiten-Peeters. This unique ability of comics as a sequential media art-form is described by Jan Baetens as,

"Comics also succeed in adding a temporal dimension that is generally missing in architectural sketches or plans thus heightening the embodied experience of something that may not yet exist as an actual building." "The fundamental image of the uncontrollably dynamic network, a

permanently expanding structure based on the mathematical figure of the cube."

"in Fever in Urbicand, where this figure first appears" (2020, p. 25)

In La Fièvre d'Urbicande, published in French and Dutch in 1985 and in English as Fever in Urbicand, in 1990, an entire city is 'infected' with a cube-like scaffolding that serves as a metaphor for the semifiction of building artificial worlds. According to Vaihinger, semi-fictions are "...essentially ingenious, and substitutes something conceived for something what is actually given." (p. 80) The physical cubes of Wittgenstein's Architecture and the scaffolding run amok in Fever in Urbicand are a visual representation of the paradox of the doubt of doubt that can infect the 'falsification strategy' or the measurement of fuzziness. Scaffolding, (both imaginary and structural) like all semifictions must only be temporary, otherwise they risk putting the means before the end. The word scaffolding in English is almost completely utilitarian and practical in its connotation and implication, but échafaudage in French has an implication of a theatrical stage or a raised platform, while pegmata in Latin implies the use of boards and can also describe a bookcase, and lastly Gerüst in German implies the 'setting up' of the superstructure. Interestingly, the Portuguese word andaime was likely taken from the Arabic ad-da'im. The fact that there are so many different words for scaffolding suggests that each word/concept evolved separately in many different times, places, and cultures, with each cultural context impressing upon it their own temporal and cultural experiences. Using building and architecture as a metaphor Schuiten and Peeters are exploring and extending the metaphysical practices that Flusser adapted from Vaihinger.

Four elements come to the fore here, none of them per se unique or exclusive to the world invented by Schuiten and Peeters, but the combination of which defines the specific stance of The Obscure Cities: (1) 
the mutual implication of fiction and reality; (2) the open definition of an integral form of architecture; (3) the focus on becoming; and (4) the emphasis on power, discipline, and resistance. (2020, p. 29)

In "Wittgenstein's Architecture", Flusser could easily be describing a scenario from The Obscure Cities, although he tips his hand near the end of the essay where he reveals the architectural backstory of his dual approaches to science fictions.

The landscape portrayed in this essay, it goes without saying, is a metaphor. Is it possible to identify it as Vienna? And is it possible for anyone entering Wittgenstein's little house in that unlikely place to make out a hint of the unsayable? What we cannot speak about we must pass over in silence. (2017, p. 77)

This 'passing over in silence' is a praxis that is similar to not explaining the punchline of a joke, or not spoiling the plot twists of a film (or comic book). Leaving the space (even a fantasy space) empty and unspeakable is itself a form of 'real fiction' that allows a space into which truth (and paper architecture) and be projected.

\section{Conclusion}

In conclusion, this dual strategy and epistemology to the contrasting means to approach useful scientific truth through the creation of fictions that can broadly be called Fictionalism reached its most complex in the writings of Hans Vaihinger, and together with several other philosophies of representation and culture such as Volkspsychologie, Wittgenstein's pragmatic linguistics and Nietzsche's phenomenology, reached a crucible of academic institutions during the interwar period in Europe into which Vilém Flusser was immersed in his early career. As an unconventional student at the Carl University in Prague, Flusser's education was disrupted by the second world war, and continued first in London and then in Brazil. Due to this unique characteristic of his career, he synthesized these strains of thought and philosophical approaches into a uniquely well-evolved philosophy of media which was well-suited to experience the mid-20th century movement into electronic communications, and to presciently clear a path of a philosophy of digital media. Fictionalism remained a prevalent approach in Flusser's work, both in Brazil and after his return to Europe. His ideas of fantasia essata and Ungenauigheit align still closely with Vaihinger's semi-fictions and real fictions - that together they can be used to probe different forms of media, architecture, law, and philosophy - especially in an era of increasing digital 'withdrawal' into complex virtual arenas that can be used as fictions to create new media praxes.

To return to the architectonic metaphor of scaffolding and housing, we can examine Flusser's essay Future Architecture from his column "Curie's Children" in Artforum which he wrote within a year of his lecture on "Science Fiction" to the TV Club in Vienna. In May of 1990 he made the connection between Habit and Networks in architecture. 
Beginning with a concept very similar to the 'scaffolding' metaphor from both Vaihinger and Schuiten-Peeters.

"People inhabit caves, tents, houses, cubes piled on top of each other. People need habit, for it is only within habit that an experience acquires meaning, just as information theory asserts that it is only within redundance or repetition that noise becomes information."

"A house is a roof and four walls; the rest is secondary." (1990, p. 35)

Flusser sees a type of modified scaffolding replacing the older versions of houses - an enduring, but still temporary, semi-fiction of scaffolding made inhabitable through advances in technology. Like the process of science and technology that made it possible, this new and evolving house-as-technological-scaffolding must be functionally attractive within a dense network of human relations.

"It must exist as a process rather than a static construction, for it must absorb new relations as its input, and it must process them into information. This information must be transmitted to its inhabitants and to other houses and to other houses and agencies. The new house must be a knot within the human network, a creative knot within which the sum of information (the sum of 'culture') at its inhabitant's disposal increases. It must be a knot built on material and immaterial cables." (1990, p. 36)

Flusser's new architecture poses a new type of dwelling place that is a constant and livable semi-fiction, in Vaihinger's terms. This semifiction is made into a literal and figurative scaffolding of cables and other structural elements. This scaffolding then forms into a new type of house or habitat, which because of its design is a node on what Flusser called a 'dialogic network'. In fact, he warned architects to keep this network open and not 'bundled' - in which case it would reflect the 'fasces' of authoritarian and totalitarian systems. But this open network becomes the technology through which science is propagated and new hypotheses are invented and tested. This extension of technology rests on the Flusser's ideas of scientific fictions from his lecture "Science Fiction" from 1988, especially the idea of moving ever closer to truth or reality by leveraging the scientific ability to be ever-less imprecise. This is the approach to scientific fictions that Flusser borrowed from Vaihinger's semi-fictions. This completes a loop as demonstrated below:

Semi-fiction-as: Scaffolding-as: House-as: Network-as:

Technology/Science Fiction-as: 'ever-less imprecise'-as: Semi-fiction

The paper architecture of Schuiten-Peeters, and the imagining and explication of this loop act as the Real Fiction, a technological blueprint which communicates the ideas to artists and technicians who will continue to build actual technologies based on the design. These two approaches taken together, the semi-real fictions and the real fictions, seen through an architectonic metaphor provides a backstory for Flusser's dual scientific fictions of 'falsification strategy' and the epistemology of improbability.

\section{References}

Baetens, J. (2020). Rebuilding story worlds: the Obscure Cities by Schuiten and Peeters. Rutgers University Press. 
Bieling, T. (2020). Fact and Fiction - Design as a Search for Reality on the Circuit of Lies. Flusser Studies, 29, 1-6.

Flusser, V. (1990). Future Architecture. Artforum, 28(9), 35-36.

Flusser, V. (2017). Wittgenstein's Architecture. In The shape of things: a philosophy of design (pp. 76-77). essay, Reaktion Books.

Flusser, V. Science Fiction. Vienna TV Club 2 March 20th (1988) Translation William Hanff (2015), Flusser Studies, 20.

Flusser V., Eisel, E., \& Ströhl, A. (2008). A New Imagination. In Writings. essay, University of Minnesota Press.

Flusser, V., Novaes, R. M., \& Zielinski, S. (2014). On doubt. Univocal Publishing LLC.

Hanff, W. (2020). Fiktions des Wissenschaft - Is Science Fiction Translatable? or is Translation a Science Fiction? Flusser Studies, 30, 1-8.

Klautke, E. (2016). The Mind of the Nation: Volkerpsychologie in Germany, 18511955. Berghahn Books.

Peeters, B., Schuiten F., \& McMillan, C. (2004). The Book of Schuiten. Casterman.

Vaihinger, H. (2009). The philosophy of "as if": a system of the theoretical, practical and religious fictions of mankind. (C. K. Ogden, Trans.). Routledge.

Artigo enviado em: 10/05/2021. Aprovado em: 15/06/2021. 